\title{
Impact of the French system of statutory visits on antenatal care
}

\author{
B BLONDEL, M J SAUREL-CUBIZOLLES, AND M KAMINSKI \\ From the Groupe de Recherches Epidémiologiques sur La Mère et L'Enfant, INSERM, Unité 149, Villejuif, \\ France
}

SUMMARY A survey of a representative sample of births in France in 1976 showed that the great majority of women receive at least the minimum antenatal care laid down by law: $4 \%$ of women missed one of the three statutory visits linked to payment of the antenatal allowance and 6\% missed the fourth visit that should take place in the ninth month. A smaller study conducted in two hospitals, one in the Paris region and the other in Nord-Pas-de-Calais, showed that the date of the first visit did not depend on a knowledge of the regulations. In one of the hospitals, where about $95 \%$ of women made more than the four statutory visits, the actual number of visits made was independent of a knowledge of the statutory number, In contrast, in the other hospital, where the mean number of visits was nearer to the statutory minimum, about half the women who said that four visits were required made exactly that number of visits and about half of those who gave three as the number made three visits.

French legislation requires a minimum of four antenatal visits for all pregnant women, in accordance with a standard pattern. Three visits, one in the first trimester and one each in the sixth and eighth months of pregnancy are the condition of a woman receiving her antenantal allowance (around $£ 250$ in 1981). A fourth visit is fixed for the beginning of the ninth month but is not linked to the payment of benefits. ${ }^{1-3}$ These four antenatal visits are free of charge. A woman may choose to consult a general practitioner, an obstetrician, or a midwife either in hospital or in private practice. The first consultation, however, must be with a doctor. ${ }^{1}$

Increasingly, the number of antenatal visits exceeds the legal minimum. The percentage of women making more than four visits rose from $49 \%$ in 1972 to $60 \%$ in 1976.4 We should ask, therefore, whether the legislation still influences the pattern of antenatal consultations.

Firstly, we examined national data to assess the extent that pregnant women comply with the regulations. We then studied the influence of legislation on antenatal care by looking at women's knowledge of the regulations and the relation between this knowledge and the antenatal care actually received.

\section{Population and methods}

We report two studies. One was an assessment, at national level, of adherence to the regulations on antenatal visits from a representative sample of 4225 women delivered in 1976, covering all France except the Rhône-Alpes region. ${ }^{5}$ The other concerning knowledge of the law comes from a survey of 1977 and 1978 in two public maternity hospitals, one in the Paris region (hospital A) on a sample of 466 women and the other in the region Nord-Pas-de-Calais (hospital B) on a sample of 371 women. In both surveys women were interviewed in hospital in the puerperium.

In the hospital study the total number of visits was analysed excluding confinements before 37 weeks' gestation; the stage of pregnancy reached at the time of the first visit was analysed excluding women who did not know the date of their last menstrual period.

In the statistical analysis the Pearson $\chi^{2}$ and the Boyd and Doll method of adjustment were used. ${ }^{8}$

\section{Results}

ADHERENCE TO THE REGULATIONS: THE NATIONAL STUDY

In 1976, for the complete sample, the percentage of women who had not made the four statutory visits were: the first-trimester visit (4\%), the sixth-month visit $(2 \%)$, the eighth-month visit $(4 \%)$, and the ninth-month visit (14\%).

It was found that $41 \%$ of the women who had not made the eighth-month visit and $66 \%$ of those- who had not made the ninth-month visit were prevented from doing so by giving birth before the expected 
date of deliveries. When women were excluded who could not make the statutory visits because of the difference between the actual and the expected date of deliveries, $4 \%$ missed at least one of the three visits linked to the payment of the antenatal allowance and $6 \%$ missed the fourth visit (in the ninth month).

These two aspects of antenatal attendance were strongly correlated: among women who had missed at least one of the first three statutory visits, 34\% missed the ninth-month visit as against $5 \%$ of those who had missed none.

ANTENATAL CARE AND KNOWLEDGE OF THE LAW: THE HOSPITAL STUDY

In hospital A $15 \%$ of women did not know that the first antenatal visit should take place before the fourth month of pregnancy, but only $5 \%$ of women consulted for the first time after that date and $80 \%$ had already made their first visit by the end of the second month of gestation. In addition, $52 \%$ of women were unaware of the number of statutory visits or gave a number under four, but only $2 \%$ actually made fewer than four visits and $80 \%$ made at least eight during their pregnancy. In hospital B only $3 \%$ of women did not know the latest date set for a first visit and $6 \%$ effectively made a first visit after that date, while $48 \%$ made a first visit within the first two months. Furthermore, $66 \%$ of women said that there were four statutory visits and in practice $44 \%$ of women made exactly four visits and $40 \%$ more than four.

In the two hospitals the date of the first antenatal visit was not significantly associated with a knowledge of the date set by law. In hospital A 95\% of women who knew the correct date and $94 \%$ of those who did not made their first visit before that date. In hospital B the figures were $94 \%$ and $100 \%$ respectively. In the same way in hospital A the number of visits made was not associated with a knowledge of the statutory number of visits. Over $70 \%$ of women consulted at least eight times during pregnancy irrespective of the woman's knowledge (table 1). In hospital B there was a significant association between knowledge and the pattern of antenatal care: $48 \%$ of women who said that the statutory number of visits was under four made fewer than four visits whereas only $10 \%$ of those who said that it was four or more and $17 \%$ of those who said that they did not know the statutory number made fewer than four visits.

This association between knowledge and the pattern of care could possibly be explained by the women's sociocultural level. In hospital B $17 \%$ of women with a lower level of education gave three as the statutory number of visits, while only $4 \%$ of those with a higher level of education gave this number $(p<0.001) ; 22 \%$ of the women with a lower level of education made fewer than four visits against $2 \%$ among women with a higher level of education $(p<0 \cdot 001)$ (table 2). Nevertheless, holding constant level of education, we found that the number of antenatal visits was associated with women's knowledge of the legal requirements (table 2). Holding constant knowledge of the statutory number of visits, however, women with a higher level of education made a significantly greater number of visits (table 2).

\section{Discussion}

The national survey shows that only a few women did not attend the minimum antenatal care laid down by law. The financial incentives of the antenatal allowance, however, do not seem to play a critical part in the participation of women in antenatal care. Not all women made the three visits to which the payment of antenatal allowance is linked, and when they had made these three visits, a large proportion of

Table 1 Number of visits by knowledge of statutory number of visits by hospital for women with at least 36 weeks' gestation

\begin{tabular}{|c|c|c|c|c|c|c|c|c|}
\hline \multirow[b]{2}{*}{ No of visits made } & \multicolumn{6}{|c|}{ Knowledge of statutory visits } & \multirow[b]{2}{*}{$\begin{array}{l}\text { All women } \\
\text { No }\end{array}$} & \multirow[b]{2}{*}{$\%$} \\
\hline & $\begin{array}{l}\text { Fewer than } 4 \\
\text { No }\end{array}$ & $\%$ & $\begin{array}{l}4 \text { or more } \\
\text { No }\end{array}$ & $\%$ & $\begin{array}{l}\text { Do } n \\
\text { No }\end{array}$ & $\%$ & & \\
\hline \multicolumn{9}{|l|}{ Hospital A } \\
\hline$<4$ & 3 & 4 & 2 & 1 & 5 & 4 & 10 & 2 \\
\hline 4 & 1 & 1 & 5 & 3 & 3 & 2 & 9 & 2 \\
\hline $5-7$ & 11 & 13 & 30 & 15 & 26 & 21 & 67 & 17 \\
\hline$\geq 8$ & 70 & 82 & 160 & 81 & 90 & 73 & 320 & 79 \\
\hline All women in $A$ & 85 & 100 & 197 & 100 & 124 & 100 & 406 & 100 \\
\hline \multicolumn{9}{|l|}{ Hospital B } \\
\hline$<4$ & 21 & 48 & 23 & 10 & 9 & 17 & 54 & 16 \\
\hline 4 & 9 & 20 & 122 & 51 & 14 & 27 & 143 & 43 \\
\hline $5-7$ & 8 & 18 & 62 & 26 & 17 & 33 & 87 & 26 \\
\hline$\geq 8$ & 6 & 14 & 30 & 13 & 12 & 23 & 49 & 15 \\
\hline All women in B & 44 & 100 & 237 & 100 & 52 & 100 & 333 & 100 \\
\hline
\end{tabular}

Hospital A: $x^{2}=7 \cdot 07$; df $=4$; NS.

Hospital B: $x^{2}=51.05 ;$ df $=4 ; p<0.001$. 
Table 2 Number of visits made by knowledge of statutory visits and education ofmother. ${ }^{*}$ Hospital B: Women with at least 36 weeks' gestation

\begin{tabular}{|c|c|c|c|c|c|c|c|c|}
\hline \multirow[b]{2}{*}{ No of visits made } & \multicolumn{6}{|c|}{ Knowledge of statutory visits } & \multirow[b]{2}{*}{$\begin{array}{l}\text { All women } \\
\text { No }\end{array}$} & \multirow[b]{2}{*}{$\%$} \\
\hline & $\begin{array}{l}\text { Fewer than } 4 \\
\text { No }\end{array}$ & $\%$ & $\begin{array}{l}4 \text { or more } \\
\text { No }\end{array}$ & $\%$ & $\begin{array}{l}\text { Do } \\
\text { No }\end{array}$ & $\%$ & & \\
\hline \multicolumn{9}{|c|}{ Mother's education I } \\
\hline$<4$ & 21 & 54 & 23 & 14 & 7 & 20 & 51 & 22 \\
\hline 4 & 6 & 15 & 83 & 52 & 11 & 31 & 100 & 42 \\
\hline$>4$ & 12 & 31 & 55 & 34 & 17 & 49 & 84 & 36 \\
\hline All women in I & 39 & 100 & 161 & 100 & 35 & 100 & 235 & 100 \\
\hline \multicolumn{9}{|c|}{ Mother's education II } \\
\hline$<4$ & 0 & & 0 & & 2 & 12 & 2 & 2 \\
\hline 4 & 3 & 75 & 39 & 51 & 3 & 18 & 43 & 44 \\
\hline$>4$ & 1 & 25 & 37 & 49 & 12 & 70 & 52 & 54 \\
\hline All women in II & 4 & 100 & 76 & 100 & 17 & 100 & 97 & 100 \\
\hline
\end{tabular}

Role of education adjusted for knowledge: $\chi^{2}=14.61 ;$ df $=2 ; p<0.001$.

Role of knowledge adjusted for education: $x^{2}=38 \cdot 31$; $\mathrm{df}=4 ; \mathrm{p}<0.001$.

"Mother's education I: not higher then end of primary school or first level of technical school.

them also made the fourth visit, which is not linked to the payment of any allowance. One possible explanation might be that the influence of financial incentives is lessened by the fact that the majority of women who do not make the statutory number of antenatal visits receive their antenatal allowance anyway after their case has been reviewed by a commission.

Many factors can stand in the way of attendance at antenatal care and reduce the incentive value of the antenatal allowance. This is especially the case for women of high parity, very young women, or women of lower social class, who, more often than other women, do not comply with the regulations ${ }^{78}$ and have inadequate antenatal care.$^{8-11}$ Firstly, there are practical obstacles, such as child minding, or lack of public transport, which are more acute in some social circumstances than others. Appreciation of the importance of prevention, particularly during pregnancy, varies greatly according to social class; women's views differ on what should be the proper number of visits for a normal pregnancy. ${ }^{12}$ Moreover, women of lower social class consult general practitioners more often than other women and, in France, general practitioners see women less often during pregnancy than obstetricians or hospital teams. ${ }^{13}$

The large difference in the amount of antenatal care received by women in the two hospitals allows us to measure the impact of legislation in two different medical environments. In so far as the women did not receive all their antenatal care from the medical teams of the hospitals surveyed, the results cannot be attributable only to those hospitals. They may with some caution be generalised to a larger population since the antenatal care of the women in the two hospitals differed little from that found in the region in which each hospital is situated. ${ }^{5}$
Many women knew the precise date by which the first visit must be made, possibly because of the long period this regulation has been in force (since $1945^{14}$ ). In this case, however, knowledge of the law does not seem to influence behaviour. At least 50\% of women make their first visit within two months of conception, and, for the few women who make their first visit after the third month, factors such as a delay in the diagnosis of pregnancy, a prenuptial conception, or a pregnancy too close to a previous one can cause a delay in initiating antenatal care. $^{815} 16$

In both hospitals a relatively large number of women did not know the statutory minimum number of consultations. This could be because not all sources give the same number. Since 1945 the National Insurance (Sécurité Sociale) regulations have stated that three visits are necessary in order to be eligible for the antenatal allowance. ${ }^{14}$ On the other hand, the public health code (Code de la Santé Publique) which regulates child and family health, lists four antenatal visits, ${ }^{2}$ the fourth of which was instituted in $1962 .{ }^{17}$ In addition the booklet sent to all pregnant women by National Insurance, containing medical and practical information, mentions four statutory medical examinations, ${ }^{18}$ as do most of the commercial books aimed at pregnant women. ${ }^{19-21}$ In these circumstances one would expect women to be equally likely to give three or four as the statutory minimum. In hospital B, however, women who gave three as the minimum were more likely to be of lower sociocultural status and to make fewer visits than those who gave the number as four.

The influence of legislation on the number of visits made by each woman during pregnancy differs according to the level of antenatal care that characterises the population served by each hospital; when the average is at least one visit a month, 
knowledge of the statutory minimum of four visits is poor and no longer has the influence that it might have had when first introduced. In contrast when average attendance is similar to the statutory minimum, the regulations provide a standard for the number of visits and then the law has an impact both through women's knowledge and through their willingness to comply with the legislation. Equally important, however, is the behaviour of the doctors and midwives who give antenatal care because they can inform pregnant women about statutory visits and, importantly, because it is often they who decide the pattern of visits during pregnancy.

\section{Conclusion}

Many factors have a role in encouraging or discouraging attendance at antenatal care, and financial incentives cannot, in themselves, ensure that all women will receive the minimum acceptable level of care. Although antenatal care exceeds the legal minimum more and more often, in some places for some women the regulations still provide a point of reference, especially when the average level of care is not very high.

This study was financed by grants from the Direction Générale de la Recherche Scientifique et Technique, the Ministère de la Santé, and the Protection Maternelle et Infantile of Seine-Saint-Denis. We thank the directors of the two hospitals concerned for permission to carry out the survey. Our thanks also go to Monique Franc and Janine Pla for their technical help.

We wish to express our gratitude to the National Perinatal Epidemiology Unit in Oxford, particularly Jo Garcia, for their advice and help for this paper.

Reprints from Béatrice Blondel, Groupe de Recherches Epidémiologiques sur la Mère et l'Enfant, INSERM, Unité 149, 16 bis avenue Paul Vaillant-Couturier, 94800 Villejuif, France.

\section{References}

${ }^{1}$ Code de la Sécurité Sociale. Articles L516 et L517. Paris: Dalloz, 1976.

${ }^{2}$ Code de la Santé Publique, de la famille et de l'aide sociale. Article L139. Paris: Dalloz, 1979.

${ }^{3}$ Arrêté du 27 août 1971 relatif aux examens médicaux pré et postnataux. Journal Officiel 1971; 9182-3.

${ }^{4}$ Rumeau-Rouquette C, Breart G, du Mazaubrun C, et al. Evolution de la pathologie périnatale et de la prévention en France. Enquêtes nationales INSERM 1972-76. J Gynecol Obstet Biol Reprod 1978; 7: 905-16.

${ }^{5}$ Rumeau-Rouquette C, Breart G, Du Mazaubrun C, Crost M, Rabarison Y. Naître en France. Paris: Institut National de la Santé et de la Recherche Médicale, 1979.

${ }^{6}$ Rumeau-Rouquette C, Breart G, Padieu R. Méthodes en épidémiologie. Paris: Flammarion, 1981.

${ }^{7}$ Blondel B, Rumeau-Rouquette C. Caractéristiques des femmes n'ayant pas le minimum légal de consultations. Le Concours Médical (in press).

${ }^{8}$ Blondel B, Kaminski M, Breart G. Antenatal care and maternal demographic and social characteristics. Evolution in France between 1972 and 1976. $J$ Epidemiol Community Health 1980; 34: 157-63.

${ }^{9}$ Taffel S. Prenatal care. United States, 1969-75. National Center for Health Statistics Series 21, No 33 . Washington DC: US Department of Health, Education and Welfare, 1978.

${ }^{10}$ McKinlay J. The new late comers for antenatal care $\mathrm{Br} J$ Prev Soc Med 1970; 24: 52-7.

${ }^{11}$ Simpson $\mathrm{H}$, Walker $\mathrm{G}$. When do pregnant women attend for antenatal care. Br Med J 1980; 281: 104-7.

${ }^{12}$ Blondel B, Kaminski M, Rumeau-Rouquette C. Les inégalités sociales de la surveillance prénatale. Influence des filières médicales et de l'opinion des femmes. In: Colloque INSERM: Conceptions, mesures et actions en Santé Publique. Paris: INSERM (in press).

${ }^{13}$ Blondel B, Kaminski $M$, du Mazaubrun $C$, Rumeau-Rouquette $\mathrm{C}$. Surveillance prénatale et filières médicales pendant la grossesse. Rev Epidemiol Santé Publique (in press).

${ }^{14}$ Ordonnance No 45-2720 du 2 novembre 1945. Journal Officiel 1945; 7297-301.

${ }^{15}$ Watkins EL. Low income Negro mothers. Their decision to seek prenatal care. Am J Public Health 1968; 58: 655-67.

${ }^{16}$ McKinlay J, McKinlay S. The influence of premarital conception and various obstetric complications on subsequent prenatal health behaviour. $J$ Epidemiol Community Health 1979; 33: 84-90.

${ }^{17}$ Decret No 62-840 du 19 juillet 1962. Journal Officiel $1962 ; 7310-2$.

${ }^{18}$ Comité Français d'Education pour la Santé. L'enfant du premier âge. Paris: Editions France-Impressions, 1980.

19 Pernoud L.J'attends un en fant. Paris: Pierre Horay, 1976.

${ }^{20}$ Cheynier JM. Que sa naissance soit une fête. Paris: Ed de la Courtelle, 1981.

${ }^{21}$ Lepage C, Pages F. En attendant bébé. Paris: Mercure de France, 1981. 